\section{Influence of Water Storage and Bonding Material on Bond Strength of Metallic Brackets to Ceramic}

Ana Rosa Costa ${ }^{1}$, Américo Bortolazzo Correr ${ }^{1}$, Simonides Consani ${ }^{1}$, Maria Cecília Caldas Giorgi ${ }^{2}$, Silvia Amélia Vedovello33, Mário Vedovello Filho ${ }^{3}$, Eduardo Cesar Almada Santos ${ }^{4}$, Lourenço Correr-Sobrinho ${ }^{1}$

\begin{abstract}
This study investigated the influence of water storage ( $24 \mathrm{~h}$ and 6 months), and Transbond $\mathrm{XT}$ and Fuji Ortho LC bonding materials on the bond strength of metallic brackets bonded to feldspathic ceramic. Four cylinders of feldspathic ceramic were etched with $10 \%$ hydrofluoric acid for $60 \mathrm{~s}$. Each cylinder received two layers of silane. Metallic brackets were bonded to the cylinders using Transbond XT or Fuji Ortho LC. Light-activation was carried out with 40 s total exposure time using Bluephase G2. Half the specimens for each bonding materials $(n=20)$ were stored in distilled water at $37^{\circ} \mathrm{C}$ for $24 \mathrm{~h}$ and the other half for 6 months. Shear bond strength testing was performed after storage times at a crosshead speed of $1 \mathrm{~mm} / \mathrm{min}$. The adhesive remnant index (ARI) was used to evaluate the amount of adhesive remaining on the ceramic surface at $\times 8$ magnification. Data were subjected to two-way ANOVA and Tukey's test $(p<0.05)$. Transbond XT showed significantly higher bond strength $(p<0.05)$ than Fuji Ortho LC. Significant differences in bond strength $(\mathrm{p}<0.05)$ were found when $24 \mathrm{~h}$ and 6 months storage times were compared between materials. ARI showed a predominance of score 0 for all groups, and higher scores at 1 , 2 and 3 for $24 \mathrm{~h}$ storage time. In conclusion, storage time and bonding materials showed significant influence on the bond strength of brackets to ceramic.
\end{abstract}

\author{
'Department of Restorative \\ Dentistry, Dental Materials \\ Division, Piracicaba Dental School, \\ UNICAMP - Universidade Estadual \\ de Campinas, Piracicaba, SP, Brazil \\ ${ }^{2}$ Department of Restorative \\ Dentistry, Restorative Dentistry \\ Division, Piracicaba Dental School, \\ UNICAMP - Universidade Estadual \\ de Campinas, Piracicaba, SP, Brazil \\ ${ }^{3}$ Department of Orthodontics, \\ Graduate Program in Orthodontics, \\ UNIARARAS - Universidade de \\ Araras, Araras, SP, Brazil \\ ${ }^{4}$ Department of Pediatric Dentistry, \\ Orthodontic Division, Piracicaba \\ Dental School, UNICAMP \\ - Universidade Estadual de \\ Campinas, Piracicaba, SP, Brazil
}

Correspondence: Lourenço CorrerSobrinho, Avenida Limeira, 901, 13414-903 Piracicaba, SP, Brasil. Tel: +55-19-2106-5345. e-mail: sobrinho@fop.unicamp.br

Key Words: shear bond strength, orthodontic bracket, ceramic, bonding, storage time.

\section{Introduction}

In clinical conditions, ceramics may sometimes serve as substrates for bonding orthodontic metallic or ceramic brackets. Hydrofluoric acid is normally used for bonding procedures to ceramic. Sixty seconds etching time and silane application for bonding to ceramic may be recommended for bonding to ceramic $(1,2)$.

Irregularities created on ceramic surface after acid treatment and silane application should be satisfactorily infiltrated by bonding material. Usually composite resins are used for this purpose (3). However, the technique is sensitive and failures in composite resins have been attributed to moisture contamination (4). Resin-modified glass ionomer cements can also be used for bonding orthodontic brackets to ceramic surfaces $(2,5)$. However, some studies have shown lower bond strength for glass ionomer cements compared with composite resins $(2,6,7)$.

Clinically, when orthodontic brackets are bonded to ceramic surface and exposed to the oral environment, some factors may influence the bond strength.

The durability of the bonding strength between orthodontic brackets and ceramic surface may be influenced by thermocycling, time and storage conditions in the oral environment (8-12). A previous work showed significant decrease in bond strength between resin cement and ceramic surface after 150-day storage (13).
However, the literature is still not conclusive regarding the storage time and materials on the bond strength between orthodontic brackets and dental ceramic.

The aim of this study was to evaluate the influence of water storage ( $24 \mathrm{~h}$ and 6 months) and bonding materials (Transbond XT and Fuji Ortho LC) on the shear bond strength of metallic brackets to feldspathic ceramic. The tested hypotheses were: 1 . no significant difference occurs between the bonding materials, and 2. no significant difference exists in shear bond strength after both storage times.

\section{Material and Methods}

Four feldspathic ceramic cylinders (Certec Advanced Ceramics, Barueri, SP, Brazil) $13 \mathrm{~mm}$ diameter $x 20 \mathrm{~mm}$ high were used in this study. The surface of all cylinders was cleaned using pumice-water slurry (S.S. White, Petropolis, RJ, Brazil), etched with 10\% hydrofluoric acid gel (Dentsply Caulk, Milford, DE, USA) for 60 s, rinsed with air-water spray for $30 \mathrm{~s}$ and air dried for $30 \mathrm{~s}$. In each cylinder, two layers of RelyX Ceramic Primer (3M ESPE, St. Paul, MN, USA) silane coupling agent were applied and dried for $60 \mathrm{~s}$. Standard stainless steel maxillary premolar brackets (Abzil; 3M do Brasil Ltda, São José do Rio Preto, SP, Brazil) were bonded to the cylinders using Fuji Ortho LC (GC America Inc, Alsip, IL, USA) resin-modified glass ionomer or Transbond XT (3M Unitek, Monrovia, CO, USA) light-cured bonding resin, 
according to the manufacturers' instructions.

The brackets were seated and positioned firmly on the ceramic surface. Excess of bonding materials was removed using a microbrush and light-activation was carried out with 4 exposures, one on each side of the bracket. Total exposure time was $40 \mathrm{~s}$ using LED Bluephase G2 (Ivoclar Vivadent, Schaan, Liechtenstein) with $1100 \mathrm{~mW} / \mathrm{cm}^{2}$ irradiance. The ceramic cylinder $(n=20)$ for each Transbond XT (3M/ESPE) or Fuji Orto LC (GC) bonding materials and storage times ( $24 \mathrm{~h}$ and 6 months) totalized 80 bonded brackets. As several brackets $(n=20)$ were bonded to the same ceramic cylinder, a punch-holed strip of black adhesive tape was used to avoid light exposure to adjacent brackets, restricting the polymerization light to the specimen being bonded $(1,2)$. Half the specimens for each bonding material $(n=20)$ were stored in distilled water at $37^{\circ} \mathrm{C}$ for $24 \mathrm{~h}$ and the other half for 6 months.

After storage, a mounting jig was used to align the ceramic-bracket interface parallel to the testing device. The shear bond test was conducted in a testing machine (Model 4411; Instron, Canton, MA, USA) with shear load applied using a knife-edged rod at a crosshead speed of 1.0 $\mathrm{mm} / \mathrm{min}$ until failure $(1,2,14,15)$. The shear bond strength $\vec{s}$ data were calculated in MPa and submitted to two-way ANOVA and Tukey's test $(p<0.05)$.

The ceramic and bracket surfaces were observed under optical microscopy (Olympus Corp, Tokyo, Japan) at $8 \times$ magnification. The Adhesive Remnant Index (ARI) modified according to Årtun and Bergland method (16) was used to classify the failure modes as follows: Score 0: no bonding resin or resin-modified glass ionomer on the ceramic; Score 1: less than half of the bonding resin or resin-modified glass ionomer on the ceramic; Score 2: more than half of the bonding resin or resin-modified glass ionomer on the ceramic; and Score 3: all bonding resin or resin-modified glass ionomer on the ceramic, along with a clear impression of the bracket mesh.

Table 1. Mean shear bond strength values (S.D.) in MPa after each storage time

\begin{tabular}{lccc}
\hline \multirow{2}{*}{ Storage Time } & \multicolumn{2}{c}{ Bonding Materials } & \multirow{2}{*}{ Tukey's test } \\
\cline { 2 - 3 } & Transbond XT & Fuji Ortho LC & \\
\hline $24 \mathrm{~h}$ & $13.70(1.97)$ & $9.12(0.70)$ & $11.41 \mathrm{a}$ \\
6 months & $10.10(1.13)$ & $5.38(0.81)$ & $7.70 \mathrm{~b}$ \\
Tukey's test & $11.87 \mathrm{~A}$ & $7.25 \mathrm{~B}$ & \\
\hline
\end{tabular}

Same uppercase letters in the row indicate no statistically significant difference for bonding material, and same lowercase letters in the column indicate no statistically significant difference or storage time $(\mathrm{p}>0.05)$.

\section{Results}

Table 1 presents the results of the shear bond strength analysis. Significant differences between the bonding materials $(p<0.0001)$ and storage time $(p<0.0001)$ were detected. The interactions between material and storage time factors ( $p=0.087187)$ were not significant.

Results for ARI are shown in Figure 1. Predominance of score 0 was observed for the 6 -month storage, regardless of the bonding material. Conversely, despite the large number of 0 scores observed for the specimens stored for $24 \mathrm{~h}$, there was increase of scores 1,2 and 3 at $24 \mathrm{~h}$ storage time.

\section{Discussion}

The first hypothesis tested in this study was rejected. The current study showed significant differences between the bonding materials $(p<0.0001)$. Transbond XT produced significantly higher shear bond strength than Fuji Ortho $\mathrm{LC}$ in all conditions. These findings are in agreement with previous studies, which also found significant differences between these bonding materials, when brackets were bonded to ceramic surface (2) or enamel surface $(6,7)$. Conversely, some studies reported that no significant difference was found between Transbond XT and Fuji Ortho LC when brackets were bonded to enamel surface $(17,18)$. The alleged difference shown between Fuji Ortho $\mathrm{LC}$ and Transbond XT may be due to the composition and viscosity of these materials (2). Presence of glass particles in Fuji Ortho LC may have reduced the effect of wetness on ceramic surface because its flow is less than the one shown by Transbond XT. The durability of the bond strength between orthodontic brackets and the ceramic surface using composite resin or resin-modified glass ionomer in clinical conditions should be evaluated. Some studies have used thermocycling as an artificial ageing method in

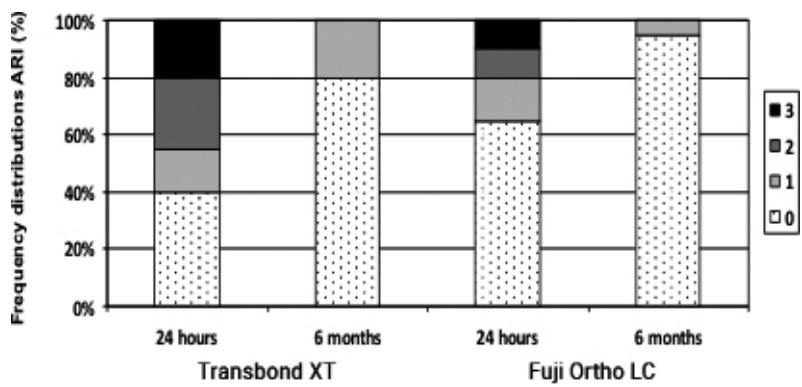

Figure 1. Frequency distributions (\%) of the Adhesive Remnant Index (ARI) scores for all groups. Score 0: No bonding resin or resin-modified glass ionomer on the ceramic; Score 1: Less than half of the bonding resin or resin-modified glass ionomer on the ceramic; Score 2: More than half of the bonding resin or resin-modified glass ionomer on the ceramic; and Score 3: All bonding resin or resin-modified glass ionomer on the ceramic, along with a clear impression of the bracket mesh. 
order to assess the durability of bracket bonding $(2,12,19)$. However, the most commonly used artificial ageing method, especially in restorative dentistry, is long-term water storage $(2,12,13,19,20)$. Bond strength decrease is believed to be caused by hydrolytic degradation of the interface components (21) and significant reduction in the mechanical properties was observed in composite resin after one year in water storage (20).

In the current study, the data showed the lowest bond strengths between the bonding materials in distilled water after 6 months. Then, the second hypothesis was also rejected. These findings are in agreement with those of a previous study, which also found that water storage for 6 months significantly reduced the bond strength, regardless the bonding materials (22). Besides, some studies have shown that the decreased mechanical properties of composite resins aged in water may occur within 2 to 6 months $(23,24)$. However, another study reported no significant difference after storage for 2 years using Transbond XT (12).

Bond strength values between 6 to $8 \mathrm{MPa}$ are adequate for orthodontic applications in oral environment (25). In the current study, brackets bonding to ceramic with strength values lower than 6.0 MPa were only obtained for Fuji Ortho LC group when stored for 6 months. Therefore, care should be taken by clinicians with the use this material because it is unable to resist forces in long-lasting orthodontic treatments.

$A R I$ values indicated that the majority of debonding failures were scored 0 , when no bonding resin-modified glass ionomer or resin on the ceramic surface was observed. However, despite the large number of scores 0 observed after water storage for $24 \mathrm{~h}$, there was increase in scores 1, 2 and 3 for $24 \mathrm{~h}$ storage time. This may be clinically advantageous because there is less adhesive to remove from the ceramic surface after bracket debonding (2).

In this context, the current study demonstrated that bonding materials and storage time were decisive factors to obtain improved bond strength between brackets and ceramic. In spite of the stronger bond strength found for the Transbond XT, the results showed that Fuji Ortho LC can be used according to the tested conditions in this study, except for a 6-month storage. Therefore, care should be taken by clinicians because bracket bonding failures sometimes occur during the later treatment stages due to heavy forces produced by the archwire or occlusal forces (12). Further studies should analyze the effect of a larger number of thermal cycles.

\section{Resumo}

Este estudo investigou a influência da armazenagem em água (24 h e 6 meses) e dos materiais para colagem Transbond XT e Fuji Ortho LCO na resistência da união de bráquetes metálicos fixados a cerâmica feldspática. Quatro cilindros de cerâmica foram condicionados com ácido fluorídrico a $10 \%$ por $60 \mathrm{~s}$. Todos os cilindros receberam duas camadas de silano. Bráquetes metálicos foram fixados aos cilindros utilizando os materiais Transbond XT ou Fuji Ortho LC. A fotoativação foi realizada com tempo de exposição total de 40 s utilizando Bluephase G2. Metade das amostras de cada material de colagem $(n=20)$ foi armazenada em água destilada a $37{ }^{\circ} \mathrm{C}$ por 24 h e outra metade por 6 meses. 0 ensaio de resistência da união ao cisalhamento foi realizado após os periodos de armazenagem à velocidade de $1 \mathrm{~mm} /$ minuto. 0 Índice de Remanescente Adesivo (IRA) foi utilizado para avaliar a quantidade de adesivo residual na superfície da cerâmica, em lupa estereoscópica com aumento de 8x. Os dados foram submetidos à Análise de Variância de dois fatores e teste de Tukey $(p<0,05)$. Transbond XT apresentou resistência de união significativamente maior do que Fuji Ortho LC. Diferença significante $(p<0,05)$ na resistência da união foi encontrada entre os períodos de armazenagem, qualquer que fosse o material para colagem. 0 IRA mostrou predominância de escore 0 para todos os grupos, com aumento de escores 1, 2 e 3 para o periodo de armazenagem de $24 \mathrm{~h}$. Em conclusão, o período de armazenagem e os materiais de colagem influenciaram significativamente a resistência da união de bráquetes à cerâmica.

\section{Acknowledgements}

This study was supported by Conselho Nacional de Desenvolvimento Científico e Tecnológico-CNPq (Grant 303928/2009-3).

\section{References}

1. Gonçalves PR, Moraes RR, Costa AR, Correr AB, Nouer PR, Sinhoreti MA, et al.. Effect of etching time and light source on the bond strength of metallic brackets to ceramic. Braz Dent J. 2011;22:245-248.

2. Costa $A R$, Correr $A B$, Puppin-Rontani RM, Vedovello $S A$, Valdrighi $H C$, Correr-Sobrinho $L_{\text {, et }}$ al.. Effect of bonding material, etching time and silane on the bond strength of metallic orthodontic brackets to ceramic. Braz Dent J 2012;23:223-227.

3. Meguro D, Hayakawa T, Kasai K. Efficacy of using orthodontic adhesive resin in bonding and debonding characteristics of a calcium phosphate ceramic bracket. Orthod Waves 2006;65:148-154.

4. Zachrisson BJ. A posttreatment evaluation of direct bonding in orthodontics. Am J Orthod 1977;71:173-189.

5. Christensen GJ. Dental cements: are they the weak link? J Am Dent Assoc 1991;122:63-64.

6. Bishara SE, Vonwald L, Laffoon JF, Jakobsen JR. Effect of altering the type of enamel conditioner on the shear bond strength of a resinreinforced glass ionomer adhesive. Am J Orthod Dentofacial Orthop 2000;118:288-294.

7. Correr-Sobrinho L, Correr GM, Consani S, Sinhoreti MA, Consani RL. Influence of post-fixation time on shear bond strength of brackets fixed with different materials. Braz Oral Res 2002;16:43-49.

8. Bishara SE, Ostby AW, Laffoon JF, Warren J. Shear bond strength comparison of two adhesive systems following thermocycling. Angle Orthod 2007;77:337-341.

9. Gale MS, Darvell BW. Thermal cycling procedures for laboratory testing of dental restorations. J Dent 1999;27:89-99.

10. Ortengren $\mathrm{U}$, Wellendorf $\mathrm{H}$, Karlsson S, Ruyter IE. Water sorption and solubility of dental composites and identification of monomers released in an aqueous environment. J Oral Rehabil 2001;28:1106-1115.

11. Trites B, Foley TF, Banting D. Bond strength comparison of 2 selfetching primers over a 3-month storage period. Am J Orthod Dentofacial Orthop 2004;126:709-716

12. Yuasa $T$, lijima M, Ito $S$, Muguruma T, Saito T, Mizoguchi I. Effects of long-term storage and thermocycling on bond strength of two selfetching primer adhesive systems. Eur J Orthod 2010;32:285-290.

13. Kern M, Thompson VP. Bonding to glass infiltrated alumina ceramic: adhesive methods and their durability. J Prosthet Dent 1995;73:240249.

14. Correr AB, Costa AR, Lucato AS, Vedovello SA, Valdrighi HC, Vedovello 


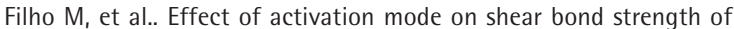
metallic brackets. Braz Dent J 2013;24:513-516.

15. Soares $E F$, Costa $A R$, Correr $A B$, Vedovello $S A$, Vedovello Filho $M$, Ogliari $F A$, de Moraes RR, et al.. Effect of composite containing an iodonium salt on the bond strength of brackets to bovine enamel. Braz Dent J 2014;25:237-240.

16. Artun J, Bergland S. Clinical trials with crystal growth conditioning as an alternative to acid-etch enamel pretreatment. Am J Orthod 1984;85:333-340.

17. Chung $\mathrm{CH}$, Cuozzo PT, Mante FK. Shear bond strength of a resinreinforced glass ionomer cement: an in vitro comparative study. Am J Orthod Dentofacial Orthop 1999;115:52-54

18. Lippitz SJ, Staley RN, Jakobsen JR. In vitro study of 24-hour and 30-day shear bond strengths of three resin-glass ionomer cements used to bond orthodontic brackets. Am J Orthod Dentofacial Orthop 1998;113:620-624.

19. Costa $A R$, Correr $A B$, Puppin-Rontani $R M$, Vedovello $S A$, Valdrighi $H C$, Correr-Sobrinho $L$, et al.. Effects of thermocycling and light source on the bond strength of metallic brackets to bovine teeth. Braz Dent J 2011;22:486-489.

20. Carrilho MR, Tay FR, Pashley DH, Tjäderhane L, Carvalho RM. Mechanical stability of resin-dentin bond components. Dent Mater 2005;21:232-241.

21. De Munck J, Van Landuyt $K$, Peumans $M$, Poitevin $A$, Lambrechts $P$, Braem $M$, et al.. A critical review of the durability of adhesion of tooth tissue: methods and results. J Dent Res. 2005;84:118-132.

22. Alsulaimani FF. Effect of lactic acid etching on bonding effectiveness of orthodontic bracket after water storage. ISRN Dentistry 2014;719608:1-6.

23. Ferracane JL, Berge $\mathrm{HX}$, Condon JR. In vitro aging of dental composites in water-effect of degree of conversion, filler volume, and filler/matrix coupling. J Biomed Mater Res 1998;42:465-472.

24. Drummond JL, Botsis J, Zhao D, Samyn J. Fracture properties of aged post-processed dental composites. Eur J Oral Sci 1998;106:661-666.

25. Reynolds IR. A review of direct orthodontic bonding. $\mathrm{Br} J$ Orthod 1975;2:171-178. 